\title{
LABIALS, VELARS AND LABIOVELARS IN GERMANIC
}

In a recent article (1995), the eminent Indologist F. B. J. Kuiper has emphasized the necessity to distinguish between at least three different layers of pre-Germanic substratum:

(A1) 'European' words with $a$-vocalism and frequent voiced aspirates, e.g. *bhabh- 'bean', *bhardh- 'beard', *bhar(e)s- 'barley', *ghasdh-'rod', perhaps *sam(a)dh- 'sand'.

(A2) Germanic words with $a-, i-, u$-vocalism, initial clusters $k n^{-}, k l^{-}$, and prenasalization, which is reflected as variation between $-b-,-m b-$, -mp-, -pp-, e.g. ON klifa 'climb', klif, kleppr, kleif 'cliff', OE climban, clif.

(A3) 'Old European' words with frequent $a$-vocalism, few consonants and lots of suffixes, reflected in the European hydronymy. Theo Vennemann has recently presented strong evidence for the view that this substratum language is cognate with Basque (1994).

Kuiper goes on to discuss two Proto-Germanic words which may belong to layer A1, viz. *babnō 'bean', which he assumes to have replaced *babo $<{ }^{*} b h a b h \bar{a}$ reflected in Latin faba and Old Prussian babo, ${ }^{1}$ and ${ }^{*} b a b m a z$, Gothic bagms 'tree', OE béam, OHG boum. He assumes dissimilation of these words to *bauno and *baumaz in West Germanic and dissimilation of *babmaz to *bagmaz in East and North Germanic, cf. Old Swedish bagn 'trunk', and concludes that the source language must have had two different root morphemes *bhabh- 'bean' and *bhabh- 'tree'.

The latter conclusion seems highly improbable to me. It is much more plausible that we are dealing with two derivatives of a single root *bhabh-, which may have carried the verbal meaning 'grow'. This leads me to a reconsideration of the possibility that *bhabh-represents the PIE root *bheH2u- in an unknown substratum language which may have branched off at an early stage. ${ }^{2} I$ have long suspected 
the existence of a western Indo-European substratum language where the PIE laryngeals are reflected as velar obstruents to a larger extent than they are in Anatolian. It seems appropriate to give vent to my speculations here. ${ }^{3}$

As I have indicated elsewhere (1989), I think that the PIE laryngeals developed from Indo-Uralic velar plosives, e.g. PIE *dheH1- 'put' < PIU *deka-, Finnish teke- 'do, make', and PIE *deH3'give, take' < PIU *tagu-, Finnish tuo- 'bring', southern Lappish duoke- 'sell'. For Armenian I have argued that PIE *Hie- and *Hoyielded $e$ - and $o$ - whereas ${ }^{*} H_{2 e}$ - and ${ }^{*} H 3 e$ - yielded $h a$ - and ho-, with voiced $h$-, respectively (1983). If PIE $*_{e}$ yielded $a$ while ${ }^{*} H_{2}$ and ${ }^{*} H_{3}$ merged with $* g h$ and ${ }^{*} g^{w} h$ in the western Indo-European substratum language, the expected correspondences fit Kuiper's category A1 perfectly. We may then conclude that *bhabh-<*bhaghw-<*bheHzw-is a natural development.

Another example where I suspect an obstruent reflecting a PIE laryngeal is the Gothic name of the s-rune sugil <*suH2l, with laryngeal metathesis in the zero grade of *seHzul 'sun', Latin sōl, cf. Go. sauil <* sāwel-, ON sól. The alternative hypothesis that Go. sugil is a dialectal variant of sauil meets with several difficulties. Firstly, there is no evidence for this type of dialectal variation elsewhere in the language. Secondly, there is no evidence for an intrusive $-g$-in Gothic, as there is in West Germanic, e.g. OE nigon < *newun, geoguð< *juwundō, Go. niun 'nine', junda 'youth'. Thirdly, it is unclear why a form from an obscure dialect should be used to designate the $s$-rune. It is more probable that the name represents an archaic symbol. ${ }^{4}$

An example to which my colleague R. S. P. Beekes draws my attention is the word for 'bridge', OE brycg, OHG brucka, if this is cognate with the word for 'eyebrow', OE brü<*H3bhruH2-, Gr. ophrũs. Here again, the semantic shift precludes the possibility of simple dialectal variation.

Dr Peter Schrijver draws my attention to OE sugu 'sow', which may be another case in point if it represents the PIE word for 'pig', OE siu. However, it seems to me that the velar may have been taken from the verb sügan 'suck' if it was not simply intrusive before vocalic case endings.

An example with an initial laryngeal which is reflected as a velar obstruent is Go. gazds 'sting', OHG gart 'goad' < *ghasdh-<*Hзesd-, 
Latin hasta 'pole, spear', Middle Irish gat 'withe'. The regular development is reflected in Go. asts 'branch', OHG ast, Gr. ózos.

A possible instance with a voiceless reflex of an initial laryngeal is Slavic kostǐ 'bone', Gr. ostéon, ${ }^{5}$ cf. especially the $a$-vocalism of Welsh asgwrn 'bone' beside Latin os. However, the meaning is not favorable for borrowing and Latin costa 'rib' rather suggests that we are dealing with two different roots here. A better example is Slavic koza 'goat' *kaǵh-<*H2eǵ-, Vedic ajá, cf. Lith.ožỹs 'he-goat' < *H2eg'-, Vedic ajás. ${ }^{6}$ The same root is recognized in Gothic hakuls, OHG hahhul 'cloak'.

Another possible instance with an initial laryngeal is OHG habaro 'oats' if this word is cognate with Latin avena, Lith. avižà, Slavic ovisŭ. It is tempting to derive the Balto-Slavic words from *avikdh< ${ }^{*}$ Hзewi-H1d 'fodder', with different simplification of the final cluster, despite Pedersen's reluctant attitude. ${ }^{7}$ However, the Germanic word may not be related because Finnish kakra and Middle Irish coirce, Welsh ceirch suggest that a different root may be involved.

A final example with a voiceless reflex of an initial laryngeal and $a$-vocalism is Latin cabö, caballus 'horse', Slavic kobyla <*kabh- < ${ }^{*} H_{1} e k w$, Finnish hepo. I find it difficult to separate these words.

The possibility of deriving Latin faba 'bean' and caballus 'horse' from *bheH2w- and ${ }^{*} H_{1} e k w$ - leads me to reconsider the labialization of labiovelars in Germanic. As far as I can see, there has been little progress here since Streitberg's unsurpassed Proto-Germanic grammar appeared in $1896 .^{8} \mathrm{As}$ a rule, PIE labiovelars were preserved in initial and intervocalic positions in Proto-Germanic but were delabialized before rounded vowels at an early stage. The development of the voiced aspirate ${ }^{*} g w_{h}$ in initial position is unclear: 'labialization to $b$ - is improbable, delabialization to $g$ - is unwarranted, assumed development to $w$ - rests on disputable etymologies' (Polomé 1987:309). Yet I think that the number of good etymologies where a PIE labiovelar is reflected as a labial obstruent in Germanic is too large to be ignored, cf. espe-

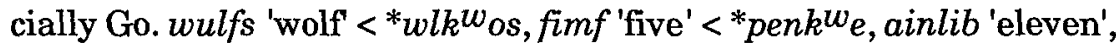
twalib 'twelve' <*-lik $w_{a}$, bilaif 'remained' <*-loik $w_{e}$, laiba 'remnant' $<{ }^{*}$ loik $w_{\bar{a}}$, ON lifr 'liver' < ${ }^{*}$ yek $w_{r}$, Go. wairpan 'throw' <* wergw-.

While the initial labial of Go. fidwor 'four' can easily have been taken from the word for 'five', the alleged assimilation of the labiovelar to the initial labial in fimf seems rather problematical to me. It is improbable that the labial feature spread phonetically through the non-labialized 
vowel. In cases of phonetic influence at a distance, we usually find either regressive assimilation resulting from mental anticipation, as in Latin quinque 'five', or progressive dissimilation, as in Spanish árbol 'tree' or in the Germanic instances which Kuiper adduces (1995:83). I therefore regard the word for 'five' as a prime example for the phonetic development of labials from labiovelars in Germanic.

In view of the delabialization of labiovelars before rounded vowels in Proto-Germanic (cf. Streitberg 1974:110f., 134), it is clear that the rise of the labial obstruent in the word for 'wolf' must have been very early. It follows that the delabialization in ON $y$ lgr 'she-wolf' must have been even earlier because it is hardly probable that an alternation between labial and velar obstruent within a single paradigm would have been preserved for a very long period of time. As the labial obstruent of OHG wulpa, OE wylf 'she-wolf' can easily have been taken from the word for 'wolf' before the consonant shift, I arrive at the following relative chronology:

(2) *wlk $w_{o s}>*^{*} w u l k w_{o s}$,

(3) ${ }^{*}$ wulkwos $>*$ wulpos,

(4) *wulkjā- > *wulgjä- (Verner's law),

(5) merger of ${ }^{*} a,{ }^{*} \bar{a}$ with ${ }^{*} o,{ }^{*} \bar{o}$,

(6) *wulgjo- > ${ }^{*}$ wulbjo- in West Germanic,

(7) *wulpaz > wulfaz (Grimm's law). ${ }^{9}$

On the basis of Go. wulfs, fimf, wairpan I now assume that the development of the labiovelars into labial obstruents was regular after resonants, and also before resonants in view of ON lifr 'liver', ofn 'oven', with later delabialization in Go. auhns, Swedish ugn. The phonetic motivation for this development was provided by the dissolution of the intervocalic labiovelars into heterosyllabic sequences of plain velar plus * $w$, which is especially clear in the case of Go. naqaps 'naked', where ON nøkkvidr and OHG nackot show gemination of the velar before * $w$, and in Go. riqis 'darkness', ON røkkr, and Go. aqizi 'ax', OHG ackus. Thus, I regard the labialization of the labiovelars as a form of cluster simplification. In the case of the root ${ }^{*} l i k w_{\text {- we may }}$ assume the former existence of a nasal present *link $w_{-}$, to be compared with Latin linquō 'leave'. 
The main objection to the explanation proposed here is the existence of the verbs Go. siggwan 'sing', sigqan 'sink', and stigqan 'thrust'. The latter verb clearly belongs to Kuiper's prenasalizing category A2, cf. ON stinga 'thrust', OHG stehhan, stehhen, sticken 'prick', stehho, stecko 'stick'. The same may be suspected for the other two verbs. The connection of Go. sigqan with Gr. heáphthe and Arm. ankanim 'fall' is no more than a possibility and the connection of Go. siggwan with Gr. omphé' 'voice, oracle' is not compelling. No conclusions can be based on Go. arhvazna 'arrow'. It is therefore possible that the labiovelars in these words belong to a layer which is younger than the labialization of the PIE labiovelars.

Cobetstraat 24

NL-2313 KC Leiden

Notes

1. The accentuation of Russian bob 'bean' and its cognates in other Slavic languages points to an original root-stressed neuter, which was evidently created as a singulative formation. Note that OPr.Babo is translated as Bonen in the Elbing vocabulary.

2. The reconstruction of the root as *bheHzu- rather than *bheuH2- is based on the Vedic imperative bodhí 'be!', the Old Irish preterit -bá, -boí, -bo 'was', and other evidence (cf. Kortlandt 1986 and Schrijver 1991:526).

3. I am indebted to Dr Dirk Boutkan and to Dr Alexander Lubotsky for detailed comments on the following.

4. If the name of the $s$-rune represents a borrowing from a West Germanic dialect (Old English?), these objections are invalid.

5. For alternative proposals, cf. Hamp 1985 and Rousseau 1990.

6 . The long vowel in the Lithuanian word is a result of Winter's law, according to which an original short vowel became long and acute before an unaspirated voiced plosive in Balto-Slavic.

7. 'Hat man denn je Schafe und Böcke mit Hafer gefüttert? Oder is der Name etwa ein Schimpfwort, von solchen Leuten ausgegangen, denen der Haferbrei nicht mundete?' (1895:42) Wild oats may certainly have been part of the livestock's diet. 
8. 'Die Bedingungen für den Eintritt dieser Verschiebung der Artikulationsstelle sind bis jetzt noch nicht ermittelt' (1974:111).

9. On the relative chronology of Verner's law and Grimm's law cf. Kortlandt 1988. Note that OHG lebara 'liver', not **-ur-, shows that the stem extension of this word arose prior to my stage (2).

\section{References}

Hamp, Eric P. 1985. 'German Bein, Old English bān; Slavic kostť' . NorthWestern European Language Evolution 6: 67-70.

Kortlandt, Frederik. 1983. 'Notes on Armenian historical phonology III: $h-$ '. Studia Caucasica 5:9-16.

Kortlandt, Frederik. 1986. 'Posttonic * $w$ in Old Irish'. Ériu 37:89-92.

Kortlandt, Frederik. 1988. 'Proto-Germanic obstruents'. Amsterdamer Beiträge zur älteren Germanistik 27:3-10.

Kortlandt, Frederik. 1989. 'Eight Indo-Uralic verbs?'. Münchener Studien zur Sprachwissenschaft 50:79-85.

Kuiper, F. B. J. 1995. 'Gothic bagms and Old Icelandic $y$ lgr'. North-Western European Language Evolution 25:63-88.

Pedersen, Holger. 1895. 'Das indogermanisches im Slavischen'. Indogermanische Forschungen 5:33-87.

Polomé, Edgar C. 1987. 'Initial PIE *gwh- in Germanic'. Festschrift for Henry Hoenigswald, 303-313. Tübingen: Gunter Narr.

Rousseau, André. 1990. 'L'alternance * $k$ - $/ \varnothing$ - à l'initiale des mots en indoeuropéen'. La reconstruction des laryngales, 149-180. Paris: Les Belles Lettres.

Schrijver, Peter. 1991. The reflexes of the Proto-Indo-European laryngeals in Latin. Amsterdam: Rodopi.

Streitberg, Wilhelm. 1974. Urgermanische Grammatik (4th edition). Heidelberg: Carl Winter.

Vennemann, Theo. 1994. 'Linguistic reconstruction in the context of European prehistory'. Transactions of the Philological Society 92:215-284. 